\title{
A STUDY ON THE MULTIPLE INTELLIGENCE LEVELS OF SCHOOL-GOING ADOLESCENT OF GOVERNMENT AND PRIVATE SCHOOL IN WEST BENGAL
}

\author{
Haru Roy \\ M.Phil Scholar, \\ Department of Education, \\ Jadavpur University, Kolkata, \\ India
}

Article DOI: https://doi.org/10.36713/epra6357

\begin{abstract}
No two individuals are alike in the universe. Students have to meet many challenges like cognitive ability, efficient methods of learning, concentration, intelligence, learning environment, and students' progress If any student wants to reach his or her goals or aims. Intelligence refers to the capacity to solve problems and the Capacity to adjust in the society. The current study focused on the different types of intelligence of school-going adolescents in these circumstances and the main aim of the study was to find out the multiple intelligence levels of school-going adolescents of government and private school in the present day. A cross-sectional survey technique was adopted with the help of a convenient sampling technique among 299 sample units.spss 221 used for data analysis The findings of the study revealed that school-going adolescents had much concern about their future, and it had both government and private school students. Significant differences were found in gender variations on Multiple intelligence at 0.05 level statistically.
\end{abstract}

\section{INTRODUCTION}

In our everyday life when we talk about a student, we must comment the students is extremely intelligent or isn't intelligent All such comments are supported by our observation of the performance of the individual considerations compared to others. Howard Gardner in 1983 introduces the multiple Intelligence theory to define them more accurately and to address the question of whether methods that claim to measure intelligence are truly scientific. In his conception, a student who masters multiplication on intelligence. Multiple intelligence is useful when we want to solve a complex problem or gain an argument, or an abstract idea, or experience something.

The multiple intelligence most burning interesting topic for many researchers after developed the multiple intelligence theory by Howard Gardner. Evolutionary psychology is the well-developed theory explaining sex differences (Wood \& Eagly, 2002[1].). Because males and females tend to have different social roles, they become psychologically different to adjust to their social roles (Eagly \& Wood, 1999\{2\}. This research also trying to know the difference in multiple intelligence among male and female students. Making use of these multiple intelligences can help us restructuring our learners to understand and develop their unique way of understanding and this empowers that person with great self-esteem and enthusiasm.

according to Gardner in his Multiple Intelligence Theory, there are 8 intelligence types. In his opinion on this theory, Gardner defended that, every individual is born with various types of intelligence and they can be improved by appropriate education, enriched media, and good support. also says these types of intelligence could be improved by an individual's upbringing (Gardner, 1993). According to Gardner, these intelligence types are-

1. Visual-Spatial Intelligence

2. Logical-Mathematical Intelligence

3. Verbal-Linguistic Intelligence

4. Musical-Rhythmic Intelligence

5. Bodily-Kinesthetic Intelligence

6. Social-Interpersonal Intelligence

7. Self-Oriented Internal Intelligence

8. Naturalist Intelligence

(Gunes and Gokcek, 2010) Gardner (1999), has put forth that there is one more intelligence type as 9th that he qualified as "Existential Intelligence" which shows 
itself with an individual's answers given to the questions about, death, eternity, and existence. The remarkable things about this theory are that each person's intelligence interacts with each other, not alone. (Gardner, 2004; Gullu \& Tekin, 2009; Sakalli, 2009).

\section{REVIEW RELATED LITERATURE}

Despite a lot of research works done on Multiple intelligence in the past, Multiple intelligence profiles of junior Secondary school students. The most similar study revealed that there is a significant difference between multiple intelligence levels of government school students and private school students. Girls have more multiple intelligence levels than boys. Government school students excel in three areas i.e, logical, interpersonal, and intrapersonal than the private school students. Boy students are good at spiritual /naturalistic intelligence (Anitha. S.T et al. 2013). [1]. Another study found that male students significantly possessed stronger in logical-mathematic intelligence, bodily-kinesthetic intelligence, and interpersonal intelligence, meanwhile, female students were significantly stronger in musical intelligence, interpersonal intelligence, and existential intelligence (Nuri, E. et al. 2014).[2]. Another study revealed that multiple intelligence like visual-spatial, verballinguistic, and interpersonal statistically significant and were able to predict academic 12 performance achievement, whereas musical intelligence was a tunable negative predictor for academic performance achievement of students (Ahvan, R.Y. et al. 2016).[3]. Some study shows that there is no substantial change concerning gender, locality, groups, and board of institution in their mean score of multiple intelligence and learning style. The correlation is not significant with the multiple intelligence and learning style (S. J, et al. 2017). [4]. Geeta, N. et al. (2017) [5] Do the study on 2228 students and she was concluded that the logical intelligence of students of graduated parents was higher than the students of nongraduate parents. Another interesting study was performing in china and the researcher revealed that the multiple intelligences predominantly fall equally in all the nine categories of multiple intelligence. The result from the t-test revealed that there is a significant difference between age, educational status and marital status of the respondents with their multiple intelligences and the result from the correlation revealed that there is a significant relationship between overall multiple intelligence of the respondent and their sections of multiple intelligence. (A. A, et al. 2016). [6].

The above summary of the previous researches on multiple intelligence displayed a clear picture of students with different types of intelligence. The present study has been tried to investigate the multiple intelligence of adolescent students in west Bengal at Kolkata, which has not been examined before. The contemporary studies on Multiple Intelligence Levels of
Adolescent Students of Government and Private School in West Bengal indicate that there are still wide knowledge gaps; improvement of the situation of attribution style among school students is one of the social agendas in India. There are no major studies available in this area, particularly on the adolescent students of the school level in West Bengal. Various researchers revealed that different factors are responsible for multiple intelligence among schoolgoing students. Among them, the gender variable of the school-going students is major trust areas of present-day research, and therefore, realizing this necessity the researcher tried to include these variables in the present study as background variables.

\section{RESEARCH QUESTIONS}

Particularly, a huge knowledge gap is noticed in the present researcher problem. Hence the researcher focuses area of the study on multiple intelligence among adolescent students. Based on the identification of resilience among the school-going children, flowing research at questions were identified: -

1. What is the present status of the multiple intelligence among the school-going adolescents in west Bengal?

2. What are the differences in the rate of prevalence of multiple intelligence among the school going adolescents concerning gender and government or private school variable in West Bengal?

\section{DELIMITATION OF THE STUDY}

The present study was delimited to the following:

1. The study sample consisted of students belong to age 14-17 years at age.

2. Only the Kolkata district was selected for the study.

3. The present study delimited to 299 samples from urban areas of the Kolkata district.

4. The sample group of students was studying at the secondary level only.

5. The study sample was collected from 6 schools only.

6. The present study delimited to the 8 dimensions of multiple intelligence.

\section{OBJECTIVES OF THE STUDY}

1. Given the basic research question and delimitation of the study, the following objectives were identified:

2. To find out the difference of multiple intelligence among the school going adolescents based on gender variable.

3. To found out the multiple intelligence between the government and private school students.

4. To find out the rate of prevalence of various dimensions of multiple intelligence like 20 Linguistic Intelligence (LiI), Logical Intelligence (LoL), Bodily-Kinesthetic Intelligence (BKI), Musical Intelligence (MI), 
Spatial Intelligence (SI) Interpersonal Intelligence (II), Intrapersonal Intelligence (INI), Naturalistic Intelligence (NI), among the school going adolescents based on gender variable.

\section{THE HYPOTHESIS OF THE STUDY}

Given the basis of research questions and objectives of the study the following Null Hypothesis was formulated:

H01: There is no significant difference between males and females in government and private schools based on multiple intelligence mean scores.

H02: There is no significant difference in the mean score of linguistic intelligence between the government and private school-going adolescents based on their gender.

H03: There is no significant difference in the mean score of logical intelligence between the government and private school-going adolescents based on gender.

H04: There is no significant difference in the mean score of Bodily-Kinesthetic Intelligence between the government and private school-going adolescents based on gender.

H05: There is no significant difference in the mean score of Musical Intelligence between the government and private school-going adolescents based on gender.

H06: There is no significant difference in the mean score of Spatial Intelligence between the government and private school-going adolescents based on gender.

H07: There is no significant difference in the mean score of Interpersonal Intelligence between the government and private school-going adolescents based on gender.

H08: There is no significant difference in the mean score of Intrapersonal Intelligence between the government and private school-going adolescents based on gender.

H09: There is no significant difference in the mean score of Naturalistic Intelligence between the government and private school-going adolescents based on gender.

H010: There is no significant difference between Government and private school-going adolescents based on multiple intelligence mean scores.

\section{STUDY DESIGN}

A cross-sectional survey framework was designed in this study with the help of a convenient sampling technique. The sample consisted of an adolescent in terms of those people, who were currently studied at any institution or organization; they were going to at any Govt. or Private school. The study was implemented on a total number of 299 sample units. Multiple intelligence had been identified as dependent factors in the study and what variations of gender and school had been seen on it. Description of Multiple Intelligences Test (MIT) based on a free publication provided by Personality Max (2011). where used as a data collection tool and there was a total of 80 items. Microsoft excels used for data tabulation and spss-v21 for data analyses.

\section{HYPOTHESIS TESTING}

To test the null-hypotheses Ho1 to Ho10, T-test, and have been used.

H01: There is no significant difference between males and females in government and private schools based on multiple intelligence mean scores.

Table 1 presenting the independent sample t-test.

\begin{tabular}{|c|c|c|c|c|c|c|c|c|c|}
\hline \multicolumn{10}{|c|}{ Independent Samples T-Test of Gender Wise Multiple Intelligence } \\
\hline Gender & $\mathbf{N}$ & Mean & SD & $\mathbf{T}$ & df & MD & $\mathbf{p}$ & $\begin{array}{l}\text { Std. Error } \\
\text { Difference }\end{array}$ & Remarks \\
\hline Male & 211 & 94.36 & 18.302 & 1.516 & 297 & 3.519 & 0.131 & 2.322 & $N^{*}(p>0.05)$ \\
\hline Female & 88 & 90.84 & 18.290 & & & & & & \\
\hline
\end{tabular}

Table 1 shows that independent sample t-test comparing the mean scores of Multiple Intelligence male students to be mean scores of Multiple Intelligence of female students found no significant difference between the mean of the two groups $[\mathrm{t}(297)=1.516$, $\mathrm{p}=.131]$. The mean of the male students was higher $(\mathrm{M}=94.36, \mathrm{SD}=18.302)$ than the mean of female students $(\mathrm{M}=90.84, \mathrm{SD}=18.290)$. 
To test the null hypotheses Ho2 to Hog t-test have been used.

Table 2: presenting the independent sample t-test.

\begin{tabular}{|c|c|c|c|c|c|c|c|c|c|c|}
\hline \multicolumn{11}{|c|}{ Independent Samples T-Test of Gender Wise different dimension of Multiple Intelligence } \\
\hline & Gender & $\mathbf{N}$ & Mean & SD & $\mathbf{T}$ & Df & MD & $\begin{array}{c}\mathbf{P} \\
\text { value }\end{array}$ & $\begin{array}{l}\text { Std. Error } \\
\text { Difference }\end{array}$ & Remarks \\
\hline \multirow[t]{2}{*}{ Lil } & Male & 211 & 11.29 & 3.261 & \multirow[t]{2}{*}{-0.45} & \multirow[t]{2}{*}{297} & \multirow[t]{2}{*}{-0.20} & \multirow[t]{2}{*}{0.648} & \multirow[t]{2}{*}{0.437} & \multirow{2}{*}{$\begin{array}{c}\mathrm{NS}^{*} \\
(p>0.05)\end{array}$} \\
\hline & Female & 88 & 11.49 & 3.845 & & & & & & \\
\hline \multirow[t]{2}{*}{ LoI } & Male & 211 & 11.25 & 3.755 & \multirow[t]{2}{*}{2.07} & \multirow[t]{2}{*}{297} & \multirow[t]{2}{*}{0.94} & \multirow[t]{2}{*}{0.039} & \multirow[t]{2}{*}{0.452} & \multirow{2}{*}{$\begin{array}{c}\mathrm{S}^{*} \\
(p<0.05)\end{array}$} \\
\hline & Female & 88 & 10.31 & 3.049 & & & & & & \\
\hline \multirow[t]{3}{*}{ BKI } & Male & 211 & 12.46 & 3.143 & \multirow[t]{3}{*}{3.16} & \multirow[t]{3}{*}{297} & \multirow[t]{3}{*}{1.30} & \multirow[t]{3}{*}{0.002} & \multirow[t]{3}{*}{0.410} & $\mathrm{~S}^{*}$ \\
\hline & & & & & & & & & & $(p<0.01)$ \\
\hline & Female & 88 & 11.16 & 3.444 & & & & & & \\
\hline \multirow[t]{2}{*}{ MI } & Male & 211 & 9.36 & 4.008 & \multirow[t]{2}{*}{-3.69} & \multirow[t]{2}{*}{297} & \multirow[t]{2}{*}{-1.85} & \multirow[t]{2}{*}{0.000} & \multirow[t]{2}{*}{0.500} & \multirow[t]{2}{*}{$S^{*}(p<0.01)$} \\
\hline & Female & 88 & 11.22 & 3.786 & & & & & & \\
\hline \multirow[t]{2}{*}{ SI } & Male & 211 & 13.86 & 3.557 & \multirow[t]{2}{*}{1.80} & \multirow[t]{2}{*}{297} & \multirow[t]{2}{*}{0.81} & \multirow[t]{2}{*}{0.072} & \multirow[t]{2}{*}{0.452} & NS* \\
\hline & Female & 88 & 13.05 & 3.581 & & & & & & \\
\hline Interpersonal & Male & 211 & 12.60 & 3.642 & 1.68 & 297 & 0.77 & 0.092 & 0.461 & NS* $^{*}$ \\
\hline & Female & 88 & 11.82 & 3.618 & & & & & & $0>0$. \\
\hline Intra-personal & Male & 211 & 13.19 & 3.630 & 2.29 & 297 & 1.05 & 0.023 & 0.462 & $\mathrm{~S}^{*}$ \\
\hline & Female & 88 & 12.14 & 3.661 & & & & & & .05) \\
\hline $\mathrm{NI}$ & Male & 211 & 10.35 & 3.525 & 1.54 & 297 & 0.67 & 0.124 & 0.438 & NS* \\
\hline & Female & 88 & 9.67 & 3.269 & & & & & & \\
\hline
\end{tabular}

i. An independent sample t-test comparing the mean scores of Linguistic Intelligence male and female students found no significant difference between the mean of the two groups [ $t(297)=-0.457, p=0.648]$. The mean score of the male students was lower $(\mathrm{M}=11.29$, $\mathrm{SD}=3.261)$ than the mean score of female students $(\mathrm{M}=11.49, \mathrm{SD}=3.845)$.

Therefore, the null hypothesis is rejected and it can be concluded that there is no significant difference in Linguistic Intelligence (LUI) of the school-going adolescents based on gender variable.

ii. An independent sample t-test comparing the mean scores of Logical Intelligence male and female students found a significant difference between the mean of the two groups $[t(297)=2.078, p=.039]$. The mean score of the male students was significantly Higher $(\mathrm{M}=11.25$, $\mathrm{SD}=3.755)$ than the mean of female students $(\mathrm{M}=10.31$, $\mathrm{SD}=3.049$ ).

Therefore, the null hypothesis is rejected and, it can be concluded that there is a significant difference in the Logical Intelligence of school-going adolescents based on gender.

iii An independent sample t-test comparing the mean scores of Bodily-Kinesthetic Intelligence male and female students found a significant difference between the mean of the two groups [t $(297)=3.169, p=.002]$. The mean of the male students was significantly Higher
$(\mathrm{M}=12.46, \mathrm{SD}=3.143)$ than the mean of female students $(\mathrm{M}=11.16, \mathrm{SD}=3.444)$.

Therefore, the null hypothesis is rejected and it can be concluded that there is a significant difference in the Bodily-Kinesthetic Intelligence of the school-going adolescents based on gender.

iv An independent sample t-test comparing the mean scores of Musical Intelligence male and female students found a significant difference between the mean of the two groups [t $(297)=3.698, p=.000]$. The mean of the male students was significantly Lower $(\mathrm{M}=9.36$, $\mathrm{SD}=4.008)$ than the mean of female students $(\mathrm{M}=11.22$, $\mathrm{SD}=3.786$ ).

Therefore, the null hypothesis is rejected and it can be concluded that there is a significant difference in the Musical Intelligence of school-going adolescents based on gender.

$\mathrm{v} \quad$ An independent sample t-test comparing the mean scores of spatial Intelligence male and female students found no significant difference between the mean score of the two groups $[\mathrm{t}(297)=1.807, \mathrm{p}=.072]$. The mean of the male students was quite Higher $(M=13.86$, $\mathrm{SD}=3.557)$ than the mean score of female students $(\mathrm{M}=13.05, \mathrm{SD}=3.581)$.

Therefore, the null hypothesis is rejected and it can be concluded that there is no significant difference in 
spatial Intelligence of the school-going adolescents based on gender.

vi An independent sample t-test comparing the mean scores of Interpersonal Intelligence male and female students found no significant difference between the mean of the two groups [t $(297)=1.689, \mathrm{p}=.092]$. The mean score of the male students was Higher $(\mathrm{M}=12.60, \mathrm{SD}=3.642)$ than the mean score of female students $(\mathrm{M}=11.82, \mathrm{SD}=3.618)$.

Therefore, the null hypothesis is accepted and it can be concluded that there is no significant difference in the Interpersonal Intelligence of school-going adolescents based on gender.

vii An independent sample t-test comparing the mean scores of intrapersonal Intelligence male and female students found a significant difference between the mean of the two groups [ $\mathrm{t}(297)=2.291, \mathrm{p}=.023$ ] The mean score of the male students was significantly
Higher $(\mathrm{M}=13.19, \mathrm{SD}=3.630)$ than the mean of female students $(\mathrm{M}=12.14, \mathrm{SD}=3.661)$.

Therefore, the null hypothesis is rejected and it can be concluded that there is a significant difference in the Intrapersonal Intelligence of school-going adolescents based on gender.

viii An independent sample t-test comparing the mean scores of Naturalistic Intelligence male and female students found no significant difference between the mean of the two groups [t $(297)=1.542, p=.124]$. The mean score of the male students was Higher $(\mathrm{M}=10.35$, $\mathrm{SD}=3.525)$ than the mean of female students $(\mathrm{M}=9.67$, $\mathrm{SD}=3.269$ ).

Therefore, the null hypothesis is accepted and it can be concluded that there is no significant difference in the Naturalistic Intelligence of the school-going adolescents based on gender.

To test the null hypotheses Ho10 t-test has been used.

Table 3: Presenting the Independent Sample T-Test.

\begin{tabular}{|c|c|c|c|c|c|c|c|c|c|}
\hline \multicolumn{10}{|c|}{ Independent Samples T-Test of Gender Wise Multiple Intelligence } \\
\hline Medium & $\mathbf{N}$ & Mean & SD & $\begin{array}{c}\mathbf{T} \\
\text { Value }\end{array}$ & df & MD & $\begin{array}{c}\mathbf{P} \\
\text { value }\end{array}$ & SED & Remarks \\
\hline Bengali & 149 & 179.195 & 23.425 & 4.141 & 297 & 10.080 & .000 & 2.407 & $\mathrm{NS}^{*}(\mathrm{p}<0.05)$ \\
\hline English & 150 & 169.107 & 17.843 & & & & & & \\
\hline
\end{tabular}

Calculated scores of Table 3 displayed the mean score difference of Multiple intelligence upon government and private school. Mean scores of total multiple intelligence of government and private schoolgoing adolescents found a statistically significant difference between the two groups $[\mathrm{t}=4.141, \mathrm{P}<0.05]$. Therefore, H010 null hypothesis is rejected and it seemed that there is a significant difference exists between government and private school-going adolescents on their Multiple intelligence.

\section{MAJOR FINDINGS}

- Taking into consideration Gender, the Multiple Intelligence mean score of the male students (94.36) is more than Female students (90.84) and the difference found between them was statistically to be not significant $(\mathrm{p}>0.05)$.

- The linguistic Intelligence mean score of the Male (11.29) students is lower than Female (11.49) students and the difference between found was statistically not significant ( $\mathrm{p}>0.05)$. 55 .

- The logical Intelligence mean score of the Male (11.25) students is more than Female (10.31) students and the difference found was statistically significant $(\mathrm{p}>0.05)$.
- Interpersonal Intelligence mean score of the Male students (12.60) is more than Female students (11.82) and the difference found was statistically not significant $(\mathrm{p}>0.05)$.

- Intrapersonal Intelligence mean score of the Male students (13.19) is more than Female students (12.14) and the difference found was statistically significant $(\mathrm{p}>0.05)$.

- Naturalistic Intelligence mean score of the Male students (10.35) is more than Female students (9.67) and the difference found was statistically not significant $(\mathrm{p}>0.05)$.

\section{DISCUSS AND CONCLUSION}

The study investigated the overall degree of Multiple Intelligence concerning the Gender variable and made a comparative study of the degree of Multiple Intelligence between male and female students belonging to the age group of 14 to 17 years in the Kolkata circle. This study also estimated the prevalence rate of different dimensions of Multiple Intelligence among school-going adolescents, which are very common in adolescent children i.e. Linguistic Intelligence (LiI), Logical Intelligence (LoI), BodilyKinesthetic Intelligence(BKI), Musical 
Intelligence(MI), Spiral Intelligence(SI), Interpersonal Intelligence (II), Intrapersonal Intelligence ((InI) and Naturalistic Intelligence (NI) and Overall Multiple Intelligence with the same respect to gender variable.

The main objective of the study was to provide a generalized assessment of multiple intelligence of school-going adolescents aged 14-17 years and to provide a comparative status between male and female students studying in different private and govt. school in urban areas. In the present study, the Multiple Intelligence mean score of the male students is more than Female students and the difference found between them was statistically to be not significant. In a similar study, it has been seen there was no significant difference between male and female adolescent students concerning multiple intelligence (Vidhya Nathan, 2017). In the present study, based on gender variable it can be said that a significant difference was found to be a significant difference in logical intelligence, bodilykinesthetic, and Intrapersonal Intelligence; and the male students are more inclined than female students in this mindset. Another side, the female students showed more intelligence in Musical intelligence than the male students; and the difference was found statistically to be significant. The educational policy framers, administrators, teachers, and teacher educators may adopt some realistic measures or strategies in the light of the present study. All of us have a common mission to provide multiple intelligence among school-going adolescents. We have to achieve that as early as possible.

\section{REFERENCES}

1. A.A, Amurthi. s.k (2016) "Study on multiple intelligence among Adolescent girls in Chennai" International Journal of Management and Applied Science, ISSN:2394-7926, Vol2, ISSUE-11, Special Issue-1.

2. "Gardner's Multiple intelligences as a predictor of academic performance achievement of high school students" Academic Journal of Psychological Sdietus,vol-4, ISSUE-4,199-205, ISSN:2333-0821.

3. Ahvan. R.Y and Pour, Z.H (2016) "The correlation of multiple intelligences for the achievements of secondary students". Academic Journal, vol-11(4), pp 141-145, ISSN 1990-3839

4. Anitha. S.T, Dr.Vannessa .J, Sreelakshmi. G (2013) "A study on the multiple intelligence levels of secondary school students of government and private school in Secunderabad" IOSR Journal of Research \& method in education (IOSR -JRME), Vol-3, ISSUE 4 (SEP-OCT 2013), PP 12-18.

5. .H, Karali. Y (2014) "Study of secondary school students Multiple intelligence areas (Malatya case)" Procediasocial and Behavioural Sciences 152(2014) 167-172, 1877-0428(2014) the Authors Published by Elsevier.

6. Batd1.v (2017) "The Effect of Multiple Intelligences on Academic Achievement : A meta - Analytic and Thematic Study" DOI- 10.12738/ESTP 2017.6.0104,DEC 17,17(6), 2057-2092. 60
7. Best, J. W. \& Khan, J. V. (2005). Research in education. New Delhi: Prentice-Hall of India Private Limited.

8. Christa Fountain Glenn(2010) "The use of Multiple intelligences concepts with middle school students and future academic achievement". Dissertation 924, spring $5-$ 2010,http://aquila.usm.edu/dissertation/924.

9. Dr. Kumar.S, Gupta.M (2016) "Effect of Family Variables on Multiple intelligences of secondary school students of India" psychology, ISSN 23485396 (E),vol-3, ISSUE -3, No.4, ISBN- 978-1-36503420-6.

10. Dr.Joshi (2016) "A study of multiple intelligences of students in context to Gender" The International Journal of Indian Psychology, ISSN:2348-5396, Vol3, ISSUE -3, No-9, ISBN:978-1-365-13820-1.

11. Dr.Kumar.S, Gupta .M (2016) "A study of multiple intelligences of secondary school students of Gujarat state" International Journal of Social Impact, vol-1, ISSUE-2, ISBN:978-1- 365-03415-2.

12. Dr.Mustafa.Y.A.S ,Dr. Jado. A.M.S, Dr. Onnoz. M.s (2014) "Types of multiple intelligences among undergraduate students at Yarmouk University in Light of Gardner's theory" International Journal of Humanities and social science, vol-4,no-6.

13. Dragoshi. $R$ (2016) " Self-efficacy: Multiple intelligences and Canadian student's Academic Performance" American International Journal of Humanistic and Social science vol2, No-4.

14. Emmiyati. N, Raysid. A.M, Brahmana, Arsyad.A \& Dirawan. D.G (2014) "Multiple intelligences Profile of Junior Secondary School Students in Indonesia" International education studies;vol-7, No.11; ISSN 1913-9020 E-ISSN 1913-9039

15. N, Dr. Gupta .S (2017) "A Study of multiple intelligences of secondary school students of Jodhpur city of Rajasthan state”. International Journal of Research in all subjects in Multilanguage,vol-5, ISSUE:8, ISSN:2321-2853.

16. N.S, Mohd. S.K, P.W (2016) "A Comparative study of multiple intelligence of students with respect to grades" The International Journal of Indian Psychology, ISSN 2348- 5396, ISSN:2349-3429, Vol 4, No.74, ISBN: 978-1-365-46362-4

17. S. k. Mangal (2017): Statistics in Psychology and Education, 2nd Edition: Phi learning Private Limited, ISBN-978-81-203-2088-8 $62 \mathrm{~S}$

18. J, Mrs. J.V (2017) " A study of multiple intelligence in Relating to learning style among Higher Secondary Student" vol 5 (ISS.6), ISSN-2394-3629(P), Intentional Journal of Research Granthaalayah. Salehi.M and Gerami.S(2013) "On the relationship between multiple intelligences and achievement among engineering student". English for specific purpose world, vol12, ISSUE -35.

19. Vidhya Nathan, S (2017) "A Study on Multiple Intelligences of Students with Hearing Impairment" The International Journal of Indian Psychology ISSN 2348-5396 (e); ISSN: 2349-3429 (p) Volume 4, Issue 2, No. 85, DIP: 18.01.018/20170402 ISBN: 978- 1365-68608-5 